\title{
Postliberale teologie as teologiese raamwerk vir die kerk se korporatiewe identiteit
}

\author{
Johan Buitendag \\ Departement Dogmatiek en Christelike Etiek \\ Universiteit van Pretoria
}

\begin{abstract}
Postliberal theology as theological reference for the church's corporate identity

This article seeks to show the importance of culture and symbols, as in the business sector in terms of corporate culture and image, so too mutatis mutandis in the church. The post liberal theology would be a basis of such an argument. A short exposition of the theology of George Lindbeck is given in order to indicate that his categories should be interpreted dynamically which means that the oneway direction of influence in the cultural-linguistic model gets dialectical, once this relation has been established. In a time of identity crises for established churches, corporate symbols are of utmost importance. Therefore, this process should be managed and exploited. Recognition of the particular has its place in the post liberal theology without abolishing ecumenism or, in the words of Lindbeck, "reconciliation without capitulation".
\end{abstract}

\section{INLEIDING}

Wanneer die begrip kerk bedink word, is daar twee randstene om te vermy, wat Ott (1999:393) 'n “uiterste Katolieke" en 'n "uiterste Protestantse" siening noem. Volgens die eerste uiterste het Jesus die kerk as heilsinstelling daargestel as synde die kanaal waardeur God en sy genade in die wêreld tereg kom. Dit bring mee dat die kerk oor 'n regsbasis vir tyd en ewigheid beskik. Dit gee aan die kerk die eksklusiewe reg op suiwere oordeel en uitspraak. Deur Goddelike dekreet giet die kerk God se liefde aan die wêreld uit. Die ander uiterste moontlikheid is dat kerk slegs daar is waar die Woord bedien en waardeer word. So word die kerk voortdurend en telkens ook nuut deur die 


\section{Postliberale teologie as teologiese raamwerk}

Woord geskep. Die gemeenskaplike belydenis van gelowiges is dan die uitdrukking van die een geloof. Die ekstreme vorm hiervan is wat 'n mens by die sogenaamde Sydney doctrine of the church van Donald Robinson en Broughton Knox vind, waar die kerk as 'n totaal hemelse saak beskou word en derhalwe hier op aarde afwesig is vanweë Christus se "sit aan die regterhand van God die Almagtige Vader" (McGrath 2000:478). Ekklesia kan dan hoogstens momenteel verstaan word wanneer die gelowiges bymekaar kom.

Die antwoord lê iewers hiertussen. Die aksie van God wat roep en die mens wat antwoord neig eo ipso tot sigbaarwording en institusionalisering. Dit beteken dat God se appelerende handelinge en mense se gehoorsamende antwoord hierop, 'n gestruktureerde kosmiese uitdrukking en kontinuïteit verkry (Heyns 1978:386). Die woord instituut spreek van 'n instelling wat gekenmerk word deur bepaalde vorme, organisasie, beleid, byeenkomste en prosedures. Die kerk is dus inderdaad instituut, anders sou dit in abstraksie vervlugtig. God kom immers konkreet in die geskiedenis van mense in, soos die teologie van veral Wolfhart Pannenberg ook toon.

Die kerk is instituut te midde van ander sosiale instellings, maar tog eiesoortig (Ott 1999:400). Die kerk as instituut en die kerk as organisme se grense val daarom ook nie saam nie. Die kerk is nie net daar waar gelowiges saam is en hulle geloof bely nie. Dit sou die koninkryk van God verskraal tot sosiale hupostasering. Net so min is die kerk ook oral daar waar Christus is. Omdat die kerk meer is as die somtotaal van sy dele, is die institusionalisering daarvan altyd kontingent.

Die kwessie ter sake is hoe hierdie twee uiterstes verdiskonteer kan word ten einde die Bybels-Reformatoriese verstaan van kerk so tot uitdrukking te bring dat die sigbaarmaking daarvan nie net hierdie saak sinvol sal uitdruk nie, maar ook sal ondersteun. Word nie hiermee geslaag nie, lyk dit of genoemde twee randstene hulle op een van die volgende wyses kan wreek. Ons leef toenemend in 'n tyd waar die kerk en sy funksionering onder geweldige spanning verkeer. In 'n ondersoek wat die Nederlandse kerke gedoen het, blyk dit dat kerke leegloop teen 'n tempo van 1\% per jaar, oftewel 100 000 lidmate per jaar (Dekker et al 1997:12-13). Ons in Suid-Afrika hoor al hoe meer hoedat die kerk gefaal het in sy opdrag en dat mense die kerke eenvoudig net nie meer kan vertrou nie. Genoemde twee scenario's van die kerk is dan eerstens dat die kerk in volstrekte institusionalisme kan verval. Dan is dit resloos gelyk an enige sosiale 
instelling en word die oogmerk daarvan niks anders as om die instituut te dien of minstens in stand te hou nie. Kerk word dan aldus Émile Durkheim 'n "totemistiese" instelling wat slegs ter wille van die groep self bestaan (Beattie 1993:220-221, 239). Die ander moontlikheid wil ek die likwidasie van kerk noem. Hiermee word bedoel die totale opheffing van die instituut en selfs ook van die gemeenskap van die gelowiges. Kerk is dan 'n abstraksie wat eerder 'n soort van waardesisteem of werklikheidsverstaan is wat opgaan in individuele en kollektiewe oortuigings. Immanuel Kant skryf in sy Religion within the Limits of Reason Alone (p 105) die volgende opsienbare sinnetjie in hierdie verband, "The gradual transition of ecclesiastical faith to the exclusive sovereignty of pure religious faith is the coming of the kingdom of God" (aangehaal deur Macquarrie 1997:190). Die verslag, "God in Nederland" $(1997: 27,121)$ wil dan ook dat alhoewel die kerk leegloop, godsdienstigheid toeneem en wel in so 'n mate dat twee derdes van alle Nederlanders hulle as godsdienstig beskou. Die ontwikkeling in die institusionele kerklike lewe en die in die persoonlike godsdienstigheid loop dus nie parallel nie.

Ons leef in 'n tyd waar alle grense ook nie summier opgehef word nie (PainterMorland 2001:116). Die sosiale antropologie leer duidelik ons kan nie anders as om in bepaalde verbande en nisse te funksioneer nie (Beattie 1993:12). Elke individuele stuk van 'n skaakspel vind immers sy sin en waarde in die omgewing waar dit is. Maar dan word grense allermins verstaan as isolasie en afskeiding, maar soos 'n mosaïekpatroon waar bepaalde middelpuntsoekende kragte mense bymekaar uitbring en wederkerend invloed op mekaar uitoefen. 'n Gemeenskap van gelowiges wat in terme van taal en kultuur geprofileer word, bied dus hierdie gedeelde waardes en standaarde vir sinvolle kerk-wees. Op hierdie vlak funksioneer die simbole, die gebruike, die legendes, die artefakte, die instellings van 'n bepaalde geloofsgemeenskap in tyd en plek. Beattie (1993:239) wys daarop dat hierdie simbole geensins van buite verstaan kan word nie, en dat die vraag dan boonop beantwoord moet word wat die betrokkenes meen hulle doen en wat hulle daarmee wil sê:

But the comparative study of the religious beliefs and practices of other cultures may suggest that in religion, no less than other forms of symbolic behaviour, reality is misrepresented if the symbol, and not the often indefinable thing that it symbolizes, is taken to be the ultimate truth. 


\section{2. 'N GEESTELIKE CURRICULUM VITAE}

Dit het in die teologie dikwels gebruik geraak om met 'n storie te begin. Ook Sallie McFague (2000) begin haar jongste boek, Life Abundant, met haar persoonlike storie wat sy vertel. Die erkenning vir hierdie insig gaan veral an Hans Frei (1974) wat met sy, The eclipse of biblical narrative, 'n hermeneutiek ontwikkel het wat die storie-aard van die Bybelse narratief sentraal stel. Sentraal in die Skrif staan dus volgens hom bepaalde makro-stories wat as primêre stories die godsdienstige verbeelding van Ou Israel en die vroeë Christelike gemeenskap aangegryp het. Die argument wentel hoofsaaklik om drie punte. Eerstens word aanvaar dat die Bybelse verhaal letterlik gelees moet word en wel dan so dat dit na bepaalde historiese gebeure verwys. Dan moet die verskillende stories van die Bybel ook so verstaan word dat dit deur een oorkoepelende storie onderskryf word en laastens moet hierdie sentrale storie ook weer tyd en plek oorstyg, of soos Frei (1974:3) dit uitdruk, hierdie één storie moet oor 'n werklikheid praat wat, “... in principle embrace the experience of any present age and reader." Op hierdie manier word die buite-Bybelse wêreld opgeneem in hierdie een sentrale werklikheid soos deur die Bybelse narratief gekonsipieer. Dit beteken met ander woorde dat die storie-aard van die Skrif nie net na die oorsprong van die kanon verwys nie, maar ook hoedat dit deur eeue heen deur Jode en Christene beleef is. Tot en met die uitvinding van die boekdrukkuns 500 jaar gelede is die Bybel as stories en nie as tekste nie verstaan. Stories is deur die geslagte heen oorgedra op verskillende maniere: visueel, soos onder andere die Christelike kuns in veral katedrale sedert die Middeleeue; musikaal, soos in lied; verbaal, soos in preke; en ritueel, soos in liturgie en fees (Frei 1974:121).

Maar Sallie McFague se aanslag spreek ook aan vanweë die inhoud van haar storie, of soos sy dit noem, haar religieuse outobiografie, oftewel bekerings - boonop vier daarvan (McFague 2000:4-9). Dit begin hoedat sy van kindsbeen af in die kerk opgegroei het en aanvanklik kritiekloos die leer en gebruike van die kerk haar eie gemaak het. Die volgende fase was aan Karl Barth se Romeine-kommentaar te danke toe sy die gans-andersheid van God besef het en sy uit haar kleinburgerlike godsdienstige kokon bevry is. Die komplement van hierdie transendente Godsbewussyn was toe sy die natuur ontdek het. Nie dat sy God in die natuur gevind het nie - daarvoor het Barth haar te duidelik bygebly - maar die natuur het aan haar 'n ervaring van behoort tot gebied. 
Gordon Kaufmann se stelling dat gegewe die nukleêre en ekologiese krisis van die afgelope dekades, geen teologie kan en durf voortgaan soos altyd nie, het aan haar 'n roepingsbesef gegee. Sentrale simbole soos God, Christus en mens moet sowel gede- as gerekonstrueer word vanuit hierdie nuwe konteks. Die teorie van die teologie het sy praktiese uitmonding dus in die hier-en-nou gevind. God se bestaan word dus immanent verstaan in die onmiddellike omgewing. Haar vierde bekering was die eksistensiële toeëiening van geloofswaarhede. Nou word daar nie meer oor God in die derde persoon gepraat nie, maar in die eerste persoon. Die oor God praat word dus 'n met God praat. Dit vestig persoonlike spiritualiteit en gebed. Sy (McFague 2000:9) maak die volgende belangrike gevolgtrekking uit hierdie geestelike curriculum vitae van haar:

First, I am a newcomer to living in this reality - I know little about it except the undeniable belief that it is reality, mine and that of everything else. Second, trying to live in God's reality in no way distracts from $m y$ reality; in fact, it enhances and fulfills it.

Wat hiervan dus belangrik is, is dat die Bybelse narratief haar gelei het na 'n eerste vlak ervaring met God en op sy beurt, het dit haar gelei na bepaalde refleksies oor die narratief.

Dit sluit nogal duidelik aan by John Cobb Jr (1993:40) se tese in sy "Becoming a Thinking Christian", naamlik dat eintlike oortuigings ("real beliefs") en uitgesproke oortuigings ("avowed beliefs"), alhoewel van mekaar te onderskei, mekaar wedersyds beïnvloed. Aan die hand van 'n analogie met die mediese wetenskap, wil Cobb (1993:17) die vertrekpunt van teologisering aantoon. Persoonlike gesondheid en welstand is in die moderne tyd vir lank deur die mediese wetenskap uit die hand van die individu geneem. Dikwels is mediese voorskrifte eerder gevolg as voor die handliggende oplossings soos byvoorbeeld rus vir byvoorbeeld hoofpyn. Maar gelukkig verander dit. Persoonlike gesondheid word toenemend die verantwoordelikheid van die betrokke individu. Eie besluite en keuses word gemaak vanuit 'n persoonlike en omvattende raamwerk. Alle Christene is ook van huis uit dus teoloë, sê Cobb. Met ander woorde daar word vanuit 'n bepaalde nis na die werklikheid gekyk en self lei dit tot uitgesproke oortuigings. Oortuigings word nie bloot uit niks gevorm nie, maar kom van buite op jou 


\section{Postliberale teologie as teologiese raamwerk}

af en dit lei na sekere uitsprake en ook optredes. Tog is jy geregtig op hierdie insigte, solank dit net geëkspliseer en getoets word (Cobb 1993:53). Die voorlopigheid is hierin duidelik aan te toon. Teologiese uitsprake is dus oop na voor en word gemaak vanuit verskillende kontekste.

McFague (2000:39-67) sien die saak van enige teologie wat sinvol werkbaar is in terme van drie aspekte: refleksie (wat deur die konteks beïnvloed word), ervaring van God se liefde (inhoud) en die Christelike gemeenskap waaruit en waarin dit gevorm word (Skrif en tradisie). Die vier Evangelies het alreeds die beginsel van pluralisme in die Christendom vasgelê. Elkeen verteenwoordig dus in die eerste plek 'n bepaalde historiese en kulturele omgewing waarbinne die konsepte en beelde figureer. Alle teologie is dus kontekstueel. Enige werklikheidsverstaan is dus waarde-gelade en daarom subjektief. Veral die feministiese teologie het aangetoon hoedat verskillende stemme van ras, klas, gender, seksuele oriëntasie, fisiese vermoëns ensovoorts, interpretasie bepaal, en meer nog, instrumente van mag word. McFague (2000:53) gaan sover om ervaring aan openbaring gelyk te stel, of minstens die ervaring instrumenteel te sien in God se openbaring. Openbaring is die verligting deur die Gees wat tot verandering en uitreiking lei. Die Bybel is die bloudruk vir 'n werklikheidsverstaan wat deur die geslagte heen, eventueel 'n Christelike paradigma tot stand gebring het. Daar is dus parameters vir Christelike teologie (of teologieë). En dit alles, sê McFague (2000:66), moet lei na 'n planetêre welsyn en universele geregtigheid.

\section{3. 'N KOMPREHENSIEWE WERKLIKHEIDSVERSTAAN}

Hierdie storie van 'n kontemporêre teoloog se verstaan van God en wêreld (teologie) dien as klankbord in terme van die oogmerk van die artikel vir my verstaan van kerk. Enersyds is McFague se verdiskontering van teologiese imperialisme ten gunste van subjektiewe vertrekpunte in terme van veral die Bybelse narratief as matrys en andersyds haar ekobewussyn as nis vir alle eksistensie, uiters belangrik.

Dit is goed om Loader (1987) se uiteensetting van die etiese teologie as matrys vir ook sekere aksente in ons teologie hier te lande, hier ter sake te maak. 'n Derde (tertium datur) moontlikheid bestaan: die etici het hulle teologie bewustelik as 'n afsonderlike moontlikheid ontplooi en nie as 'n vermenging van ortodoksisme en modernisme nie. 
Laasgenoemde erken geen onderskeid tussen kennis en geloof nie en dus ook nie werklik 'n transendente God nie en eersgenoemde het in openbaringspositiwisme verval wat gepoog het om waarheid in statiese kategorieë, proposisies en konsepte uit te druk. Die etici se antwoord was dus geen bemiddelingsteologie nie; hulle het nooit aan twee teorieë probeer vashou nie (geloof en rede), maar albei in 'n enkele teorie tuisgebring. Die redelike deel van die teorie is die kleiner een van twee konsentriese sirkels en die geloofskomponent is die buitenste. Die teologie rig hom op die verstaanbare proposisies wat gelowiges oor God maak. Uiteraard kan dit nie die volle waarheid omvat nie, maar wel die affiniteit tussen Goddelike en menslike gees (testimonium Spiritus Sancti) - en dit is geloofskennis wat nie vir wetenskap toeganklik is nie, omdat dit getuig van 'n lewende ontmoeting tussen God en mens. Daar bestaan 'n affiniteit tussen God se Selfbekendmaking of openbaring en die menslike gees en daarom kan die mens van God weet en Hom ontmoet. Dit is 'n ontmoeting met die waarheid, maar geen rasionele deurvorsing daarvan nie.

Met die teologie van Barth as vertrekpunt, wil ek ook bepaalde persoonlike aksente byvoeg. Eerstens spreek die dialoog tussen die teologie en natuurwetenskappe 'n mens so aan, dat ek van oortuiging is dat hierdie insigte onontbeerlik vir teologie is. Veral die bydrae wat die kwantumfisika en molekulêre biologie in hierdie debat gemaak het, oordeel ek as uiters waardevol. In kort is die winspunte van die kwantumfisika vir die teologie volgens John Polkinghorne (1998:32-34) die volgende: die fisiese wêreld is vol verrassings, suiwere objektiwiteit bestaan nie en daarom ook geen universele epistemologie nie, holisme omvat sowel nie-empiriese verstaan as subjek-beïnvloeding van die werklikheid. In kort beteken dit dat die klassieke realisme plek gemaak het vir 'n kritiese realisme (Barbour 2000:75). Die winspunte van die molekulêre biologie is dat kulturele evolusie gebaseer word op bepaalde biologiese prosesse wat outopoieties voltrek word (Du Toit 2000:522). Die ekologiese debat het die oë van die kerk oopgemaak om verby die antroposentrisme van die skepping (waarin Barth ons in 'n groot mate gelos het) te kom. Daarom kon die mens sy relatiewe plek in die kosmos raaksien. Moltmann (1985:159-160) wys op die konsentriese sirkels of nisse in die skeppingsverhaal van $P$ die atmosfeer, die geosfeer, die biosfeer - wat in harmonie tot mekaar moet staan. Daarom is die konsumeristiese praktyke van die Eerste Wêreld so afkeurenswaardig 


\section{Postliberale teologie as teologiese raamwerk}

(McFague 2000:85-93). Die paradigma van om die wêreld "te onderwerp en daaroor te heers" (Gen 1:28) moet vervang word met 'n "bewoon en bewerk" (Gen 2:15). Geiko Müller-Fahrenholz (1995:108-112) stel dan ook die begrip oikodomé (o a in 2 Kor 13:10; Rom 14:19; Ef 2:21) voor om hierdie totale huishouding van God uit te druk. "If air, water, land, time and knowledge are cosmic properties, humans can only enjoy their use, not own them - which calls for the rediscovery and elaboration of leasing and tenancy rights" (Müller-Fahrenholz 1995:150). Die laaste aksent het gekom by die internalisering van die narratiewe teologie se hermeneutiek: "Biblical interpretation became an imperative need, but its direction was that of incorporating extra-biblical thought, experience, and reality into the one real world detailed and made accessible by the biblical story - not the reverse" (Frei 1974:3). Byna soos die entropiebeginsel se tydspyl, beteken dit dat die werklikheid van binne geken word, maar wel so dat mens aanvanklik (minstens sinkronies) eerder óbjek as subjek is. Anders as die liberale teologie wat die Bybelse narratief aan die wêreld se werklikheid wil yk, word dit hierdeur omgedraai en absorbeer die Bybelse narratief die wêreld:

Stated more technically, a religion can be viewed as a kind of cultural and/or linguistic framework or medium that shapes the entirety of life and thought. It functions somewhat like a Kantian a priori ........ Like a culture or language, it is a communal phenomenon that shapes the subjectivities rather than being primarily a manifestation of those subjectivities.

(Lindbeck 1984:33)

Heinrich Ott (1999:402) sê dit nogal ook:

Nicht durch meine Entscheidung erzeuge ich die Solidarität mit einem anderen Menschen, sondern die Solidarität ist gegeben, und sie wird dann jeweils für mich verpflichtend, so, daß ich meine Entscheidungen auf sie ausrichte. Ich $<<$ realisiere $>>$ gleichsam in meinem solidarischen Verhalten das, was je schon real meiner Entscheidung vorgegeben ist. 
Die antwoord op die klassieke vraag van wat is eerste, die kerk of die individu, word dan ook hiermee geïmpliseer. Miskien is dit wel bietjie van 'n onbillike teenoor-mekaarplaas van sake, maar tog kies ons vir die kerk wat die individu voorafgaan ${ }^{1}$. Volgens die Heidelbergse Kategismus, Sondag 21, het mens deel aan die verkiesing, omdat jy aan die gemeente behoort ${ }^{2}$. Daarom is dit verkeerd om die subjek van die belydenis in die enkele, belydende mens te soek. Die kerk as gemeenskap is dan die subjek van die belydenis. Die individuele gelowige bely dan soos en saam met die kerk van alle eeue waarin hy/sy as 't ware in "die wolk van getuies" opgeneem word. In die kerk is die geheel altyd meer as die som van sy dele!

Dit is hieruit reeds duidelik dat die sake waarom dit dus wesenlik in 'n werklikheidsverstaan gaan, die objek, die subjek en die verhouding daartussen is. A M K Müller (1978:9) het destyds sy opsienbare boek, Die Präparierte Zeit, saamgevat deur te sê dat die oorlewingskrisis in der waarheid 'n waarnemingskrisis is. Verabsolutering van die objek sou Kartesiaans uitgelê kan word en wel in die sin dat die werklikheid dermate gekwantifiseer word dat waarheid dit is wat gekatalogiseer, gerubriseer, geïsoleer kan word. God word uiteraard hiermee uit die werklikheid verklaar, of soos in die geval van Stephen Hawking in die objekte-wêreld opgelos (angehaal ${ }^{3}$ deur Van Huyssteen 1998:58):

[I]f we discover a complete theory, it should in time be understandable in broad principle by everyone, not just a few scientists. Then we shall all, philosophers, scientists, and just ordinary people, be able to take part in the discussion of the question of why it is that we and the universe exist. If we find the answer to that, it would be the ultimate triumph of human reason - for then we would know the mind of God.

\footnotetext{
${ }^{1}$ Hendrik Berkhof (1977:42-50) het hierdie saak beredeneer en kom tot dieselfde konklusie.

${ }^{2}$ Vergelyk die Kort Begrip se Vraag 40 wat weer meen jy behoort aan die gemeente omdat jy uit-verkies is!

3 Dit is tog opmerklik dat Hawking (1994:178-179) dit later versigtiger formuleer: "If a complete unified theory was discovered, it would only be a matter of time before it was digested and simplified in the same way and taught in schools, at least in outline. We would then all be able to have some understanding of the laws that govern the universe and are responsible for our existence." Dit is waarskynlik toe te skryf aan sy (Hawking 1993:35) volgende uitspraak, "There is a subspecies called philosophers of science who ought to be better equipped..Maybe I'm being a bit harsh on philosophers, but they have not been very kind to me."
} 


\section{Postliberale teologie as teologiese raamwerk}

Verabsolutering van die subjek weer, beteken dat die menslike bewussyn die een en die al word. Die Idealisme soos veral deur Hegel uitgedruk, het subjek en objek se verskil in die subjektiewe bewussyn opgelos (Ward 2000:xxvii). Ook dit is 'n oorwinning van die immanentisme, want die buitenste behoort ontologies aan die binneste. Fichte druk dit treffend uit: "Die Welt muß mir werden, was mir mein Leib ist" (Mildenberger 1981:33). Gees alleen is werklik en materie is werklik slegs in soverre dit die gees dien, aldus Hegel in sy Phenomenology of mind (p 86), soos aangehaal deur Macquarrie (1997:217):

Spirit is alone Reality. It is the inner being of the world, that which essentially is, and is per se; it assumes objective, determinate form, and enters into relations with itself - it is externality (otherness), and exists for itself; yet, in this determination, and in its otherness, it is still one with itself - it is selfcontained and self-complete, in itself and for itself.

Die verhouding tussen objek en subjek erken in beginsel die wesenlike onderskeid - een van die basiese kenmerke van die postmodernisme is immers hierdie différe(a)nce (Derrida). Painter-Morland (2001) wil dan ook verskeidenheid of verskil opnuut binne die een, heilige en algemene kerk waardeer. Wanneer dit nie gebeur nie, vind dekontekstualisering plaas, met ander woorde 'n abstrakte opvatting van tyd wat dus verlies aan geskiedmatigheid en kwaliteit inhou. Slegs die algemene en die universele is dan van belang en elke unikum word geweer. In sy Sein und Zeit het Martin Heidegger erkenning aan temporaliteit gegee, met name die hier en die nou (daarom is dit opmerklik dat hy ook eerder van die perfectum en nie van die gewone aoristus vir die verlede gebruik maak). Waarheid is dan vir Heidegger geen proposisie nie, maar 'n gebeure in die Dasein (Macquarrie 1999:26). Derrida sou later hierop voortbou.

\section{POSTLIBERALE TEOLOGIE}

Hierdie debat is ook gevoer deur George A Lindbeck met sy opsienbare boek, The Nature of Doctrine wat in 1984 verskyn het. Die slothoofstuk het dan ook die vooruitsig van 'n 
"Postliberale teologie" daargestel ${ }^{4}$. Hy bedoel dit eintlik heel eenvoudig, naamlik dat die tyd vir liberale teologie, by name die Verligting se manier van doen, agterhaal is en ons daarby verby moet kom. In hierdie sin is hy dan ook 'n postmodernis wat wesenlik 'n protes teen modernisme wil aanteken. ${ }^{5}$ Ander eksponente van hierdie oortuiging is Hans Frei, Stanley Hauerwas, William Placher en ander. Vra mens na invloede op hierdie mense, sou mens inderdaad met Karl Barth moet begin. Omdat hy so sterk teen die liberalisme gekant was, was hy eintlik self 'n postliberale teoloog. Maar ook die raakvlakke met Thomas Kuhn, Ludwig Wittgenstein, Peter Berger, Richard Niebuhr, selfs Paul Ricoeur en Sallie McFague en ander se name is in hierdie verband belangrik.

William Placher (1997:344) bied die volgende samevattende oorsig van Postliberale teologie aan.

- Dit is non-fundamentalisties. Waarheid is altyd in terme van die konteks te verstaan en alle ervaring bied sig geïnterpreteerd aan. Die hamer voor my is nie maar net 'n stuk yster met 'n steel van hout nie, maar weliswaar nuttige gereedskap van mense (Lindbeck 1984:114).

- Dit staan afsydig teenoor sistematiese apologetiek. Geen filosofie of wetenskap kan hoegenaamd die konteks (taal) vorm vir die Bybelse boodskap nie. Alleen ad hoc skakeling is moontlik.

- Dit erken die verskille tussen godsdienste. Die bekende godsdienskundige, Mircea Eliade, het die benadering waarteen die Yale Skool hulle juis afgegrens het, met krag gepropageer. Erkenning aan diversiteit en kultuur-eie is 'n gegewene.

\footnotetext{
4 Eintlik is dit nie 'n "teologie" in die ware sin van die woord nie. Dalk eerder 'n hermeneutiese uitganspunt, of soos iemand al opgemerk het, 'n momentele "teologiese keelskoonmaak" (Phillips \& Okholm 1996:43; 46). McGrath (1996:23) sien dit nietemin as die belangrikste ontwikkeling in die teologie sedert 1980.)

5 Tog was die keuse van die woord dalk ook nie te gelukkig nie, want in die tagtigerjare van die vorige eeu toe die boek verskyn het, het Margaret Thatcher en Ronald Reagan die politiek van die westerse wêreld oorheers met die gevolg dat postliberaal met konserwatief (die twee genoemde leiers se politieke partye) geassosieer kon word. Dit behoort duidelik te wees dat die keuse van hierdie woord, niks met die politiek of konserwatisme te doen het nie!
} 


\section{Postliberale teologie as teologiese raamwerk}

- Dit benadruk die Bybelse verhale waardeur gelowiges God destyds ervaar het en verstaan die hede in terme daarvan. Vandaar word ook die naam "Narratiewe teologie" soms in hierdie verband genoem.

Hierdie basiese trekke van die Postliberale teologie het ook in die Bybelwetenskappe uitdrukking gevind (Placher 1997:344). Wayne Meeks wou die sosiale en antropologiese kontoere van die Nuwe Testament blootlê. Hy het hom afgegrens teen die subjektiewe individualisme van die eksistensiële hermeneutiek. Brevard Childs weer herinner ons daaraan dat die Bybel is soos dit is en dat hierdie teks binne 'n bepaalde historiese gemeenskap as kanon gefunksioneer het. Die histories-kritiese teoloë werk dus in de rwaarheid met 'n ander konteks. Die outoriteit van die Bybel lê nie in die teks self nie, maar in die destydse konteks, met ander woorde hoe 'n bepaalde gemeenskap dit toe aangewend en verstaan het. Daarom wil die Postliberale teologie nie die Bybelse storie met 'n moderne storie vervang nie, maar wil eerder die moderne storie intrek in die Bybel se storie. Dit gaan dus nie om ekstratekstualiteit nie, maar om 'n intratekstualiteit (Lindbeck 1984:114). Teologie vind sy matrys in 'n deskriptiewe intrabybelse paradigma.

Lindbeck stel die drie aksente van objektivisme, subjektivisme en die wisselwerking hiertussen op eiesoortige wyse aan die orde ten einde die aard van die belydenis en dus eintlik maar ook van kerk, aan te dui.

\section{- Proposisionalisme (of objektivisme)}

Dit lê duidelik klem op die kognitiewe rol in geloof en maak dus waarheidsaansprake. Openbaring is dus bloot 'n aantal stellings vanuit 'n universele rasionaliteit wat sy wortels in die Verligting terugvind. Die werklikheid word dus as 'n gegewene beskou. Godsdiens is hiervolgens ook nie anders as 'n filosofie of natuurwetenskap in hulle klassieke gedaante nie (Lindbeck 1984:16). Elke proposisie of uitspraak wat eenmaal vals is, is altyd vals en wat eenmaal waar is, is altyd waar, want daar is nie so iets soos konteks of grade van waarheid nie. "Those who are to some degree traditionally orthodox understand the propositional truth that they attribute to religious statements as a function of the ontological correspondence or 
'isomorphism' of the 'structure of knowing' and 'the structure of the known." (Lindbeck 1984:47). Die Postliberale teologie is kennelik van oortuiging dat geen mensetaal univokaal oor God kan praat nie. Enige sodanige poging is 'n kombinasie van duidelike onsekerheid gemeng met naïwiteit (Lindbeck 1984:21).

\section{- Ervaringsekspressiwisme (of subjektivisme)}

Dit interpreteer godsdiens as non-informatiewe simbole van innerlike gevoel, houdings en eksistensiële oriëntasie. Lindbeck (1984:21) sien die tree hierheen as die gevolg van Kant se Kopernikaanse ommeswaai van die objek na die subjek toe. Dit is veral gevestig deur Schleiermacher met sy "absolute afhanklikheidsgevoel" (Lindbeck 1984:16), Paul Tillich met sy "ultimate concern" (Lindbeck 1984:31) en andere. Bernard Lonergan (Method in theology) word verwyt dat hy hom hieraan skuldig maak, deur te verklaar dat verskillende godsdienste bloot net uitdrukking is van 'n ervaringsapriori wat alle mense gemeenskaplik het en wat ook die norm en maatstaf word (Lindbeck 1984:31). So word die kwaliteit van godsdienste gemeet aan die waarskynlike kongruensie aan dusdanige ervaringe (Lindbeck 1984:47). Dit beteken dus dat ' $\mathrm{n}$ godsdiens non-kognitiewe simbole van innerlike ervaring is. Op die ervaring volg die vormgewing van die teologie (McGrath 1997:21). Lindbeck (1984:77) redeneer tereg dat die waarheid soms juis anders is as die ervaring en dat vormgewing aan ervaring dalk ook net subjektiewe selflegitimasie kan wees!

- Kultureel-linguïsties (of 'n dinamiese netwerk van verhoudings)

Godsdienste is soos tale - die een is nie meer waar as 'n ander nie - en funksioneer soos 'n kulturele raamwerk wat die betrokkenes se lewe en oordeel vorm (Lindbeck 1984:33). Dis soos 'n idioom in taal wat die werklikheid (ook innerlike gevoelens) beskrywe. "Like a culture or language, it is a communal phenomenon that shapes the subjectivities of individuals rather than primarily a manifestation of those subjec-tivities." (Lindbeck 1984:33). Daarom is 'n godsdiens soos 'n taal wat aangeleer word, grammatika, woordeskat en al. Die grammatika is die reëls, terwyl die simbole, rites, stories weer die woordeskat is (Lindbeck 1984:81). Die belydenis (grammatika) bied nou die gemeenskapsgrense van gesprek, houdings en optrede. 


\section{Postliberale teologie as teologiese raamwerk}

Ons kan nie weet wat dit beteken om deur geloof in Christus gered te wees nie, as ons nie linguistiese ruimte het wat begrippe soos "geloof", "red" en "Christus" verduidelik nie. Die teks skep dus die konteks en nie andersom nie. Die significatum verander nie, wel die significandi. Anders as byvoorbeeld Gogarten en baie ander wat die evangelie in die idioom van die moderne mens vertaal het, word veranderende wêreldbeskouings deur een en dieselfde godsdiens vertolk. As "tweede vlak uitsprake", is dit ook nie nodig om die klassieke belydenisse soos die van Nicea of Chalcedon te verander of aan te pas nie - dit moet deur Christene sowel as nie-Christene verstaan word as die taal- of spelreël wat diakronies die hoofstroom van die Christelike identiteit vorm (Lindbeck 1984:95-96). (Hieruit behoort dit ook duidelik te wees dat "kultuur" nie hier 'n etniese verskynsel is nie. Lindbeck het heelwat geleun op Geertz se verstaan van kultuur as suiwer 'n historiese raamwerk soos uitgedruk in simbole en by wyse waarvan mense kommunikeer en leef (kyk Van der Merwe 1996:673-374)).

Kom ons kyk ter illustrasie na die bekende oortuiging van die Hervorming, te wete sola fide. Eersgenoemde interpretasie (proposisionalisties dus) sal dit verstaan as feitelike waarheid, die ervaringsekspressiewe verstaan as uitdrukking van ervaring van God se reddende almag en die regulatiewe verstaan sal dit as rigtinggewend verstaan, naamlik Christene moet so oor hulle redding handel en praat dat dankbaarheid teenoor God gekommunikeer kan word in plek van eiegeregtigheid. As mens op die proposisionalistiese wyse redeneer, kan twee kerke wat in die geskiedenis verskil het (RoomsKatolieke en Protestante) nooit saamstem nie want die stellings bly absoluut. Terwyl 'n kultureel-linguistiese wyse jou lei na 'n nuwe werklikheid waar konsensus wel moontlik kan wees binne die nuwe konteks. Daarom is kerk ook kategoriaal toereikend (Lindbeck 1984:48) en intrasistemies konsistent (Lindbeck 1984:64).

Van die kritiek wat teen Lindbeck uitgespreek is, was dié van McGrath in sy boek The Genesis of Doctrine ([1990] 1997) en wat hy herhaal het in 1995 by die Wheaton Theology Conference wat postliberales en evangelikales in konferensie bymekaar gebring het, sekerlik die felste. Dit lê nie in die skopus om nou hierop in te gaan nie, maar in effek word drie sake in die kritiek aan die orde gestel, naamlik die Postliberale teologie se 
intrasistemiese hantering van die waarheid, die gesag van die Bybel wat deur sommige anhupostaties ("draining the blood of Christ") verstaan word en die aksiomatiese vertrekpunt in Jesus (Phillips \& Okholm 1996:35-43). Na my oordeel oorreageer McGrath in sy kritiek, waarskynlik ook omdat sy teologie nie baie anders is nie (nie lank na Lindbeck se The nature of doctrine verskyn McGrath se The genesis of doctrine). Mens kry die indruk dat McGrath in sy kritiek nie besef dat Lindbeck se uiteensetting van die kerk en belydenis, eerder modelle is as konkrete voorbeelde nie. Om uitsonderings aan te toon (McGrath 1997:16) of selfs foute, hef tog nie die model op nie! Polkinghorne (1998:23) druk 'n model so uit: "The success of models, therefore, is always modest, depending upon the exploitation of partial similarities and not pretending to yield a completely valid representation of the entities being discussed." Na aanleiding van Bruce Malina kan Geyser (2000:539) ook daarop wys dat modelle 'n heuristiese funksie vervul. Modelle spoor die ondersoeker aan om patrone, korrelasies en verbande uit die voorhande data te soek. Dit gaan dus ten diepste om sinvolle samehange raak te sien. Dit is dus bloot instrumente. Daarom moet McGrath $(1996: 33,259)$ ook vir Lindbeck nie in 'n kassie plaas en hom dan kritiseer as hy nie volledig daarin pas nie. Die verskil tussen Lindbeck en McGrath se twee boeke is dalk eerder soos diakronie en sinkronie - soos die onderskeie titels in 'n mate ook aandui. Lindbeck dink ook meer in die gees van taal as 'n sisteem van arbitrêre tekens en simbole wat 'n netwerk van relasies en verskille vorm. Woorde is nie foto's van die werklikheid nie! Betekenis realiseer dus binne die teks self. Wentzel van Huyssteen (1999:69-86) se kritiek lyk meer geregverdig en sy voorstel dat in plaas van 'n non-fundamentalisme of anti-fundamentalisme by die Postliberale teologie, 'n post-fundamentalisme meer angewese sou wees. Alleen so kom mens uit die epistemiese vaarwater van relativisme (Lindbeck sou natuurlik antwoord dat die konteks of sisteem hierdie korrektief wel bied).

Winspunte van die Postliberale teologie, sê McGrath (1996:35), is die sentraalplasing van die Christendom en die weiering om die liberale teologie se nivellering van alles na te volg; die duidelike uitgangspunt van die Bybel as die basiese bron vir Christelike verstaan en waardes te erken; en die ononderhandelbaarheid van Jesus Christus wat die hart van die lewe en denke van die kerk is. Die teosentrisiteit soos deur Barth verstaan, in plaas van die antroposentrisme van die Verligting en Arminianisme, is 
volgens Clark (Phillips \& Okholm 1996:109) 'n belangrike kenmerk van die Postliberale teologie. Vir ons doeleindes kan die lys verder aangevul word. Veral die feit dat die gemeenskap of groep so integraal deel van die Postliberale teologie vorm teenoor 'n Evangelikaliese individualisme, is uiters belangrik. Maar dan moet gemeenskap ook kultureel verstaan word en dit gee ook ruimte vir ekwivokaliteit ${ }^{6}$. Die sinkrone verstaan respekteer die situasie oftewel die aktuele verbinding tussen objek en subjek. Die algemene belydenisse word nietemin onveranderd gehandhaaf en gerespekteer, nie om sentimentele redes nie, maar omdat dit spreekreël vir die kerk is (Lindbeck 1984:80). Dit is opmerklik dat hierdie verstaan van die belydenis in die kerk al eintlik bekend geraak het deur Van Ruler (1972:94):

Als spreekregel kan die belijdenis geen inhoud van de prediking der kerk zijn. Wanneer de kerk - predikend - spreekt, zal zij er goed aan doen, de regels in acht te nemen.... Maar nou moet zij ook weer niet .... alleen maar die regels gaan spreken, alleen maar rijtjes uit de grammatica gaan opzeggen. Zij moet de levende taal des Geestes spreken, puttend uit de volheid van de Heilige Schrift en handelende over alle dingen der totale existentie.

Daarom is belydenisse ook tweede-orde uitsprake omdat dit intrasistemies en nie ontologies nie funksioneer (Lindbeck 1984:94). Dit druk die grammatika van die gemeenskap uiten nie die leksikon nie! Die evangelikaliese probleem dat die Bybel se gesag in die Postliberale teologie ontneem is (Phillips \& Okholm 1996:39, 129, 160, 166), is soos om 'n sokkerwedstryd met rugbyreëls te beoordeel. Die vraag is immers nie soseer of die Skrif gesag het nie, maar eerder hoe dit gesag het. Wat Lindbeck (1989:255) dan "ressourcement" - terugkeer na die Bybel - noem, is vir hom ook die grootste enkele rede vir die suksesse van die ekumene van die twintigste eeu. Karlfried Froelich ([Fretheim \& ]Froelich 1998:14) wys in elk geval daarop dat die begrip auctoritas in die kerk van die pre-Romeinse tydvak afstam waar dit nie wetlike

\footnotetext{
6 Alhoewel Tanner (1997:157-159) basies postliberaal redeneer, is sy tog revisionisties en wil steeds 'n bepaalde eenheid onderliggend aan pluralisme sien. Tanner slaag dus nie daarin om van Paul Tillich los te kom nie. Om die Postliberale teologie darem van "ghetto-teologie" te beskuldig, is onbillik (Phillips \& Okholm 1996:109). Lindbeck is in elk ook té bekend as ekumeniese teoloog. Dialoog intra- en interkerklik is die sleutel.
} 
afdwingbaarheid beteken het nie, maar begeleiding en advies. Terence Fretheim (Fretheim [\& Froelich] 1998:81) voeg by dat die probleem van Skrifgesag eerder 'n interpretasieprobleem is as iets anders. Die relasionaliteit is dan geleë in die gemeenskap (kategoriale raamwerk) se betrokkenheid by die Skrif soos dit tyd en plek gebonde is: "The text, in effect, moves with the community for whom it has significance" (Fretheim \& Froelich 1998:91).

Kathryn Tanner (1997:36) het in haar boek, Theories of Culture, eg postliberaal daarop gewys dat kulture nie soseer in geskiedenis nie, maar eerder in 'n ruimtelike sin verskil. Nie diakroniese nie, maar sinkroniese tyd is van belang (Tanner1997:35). Dit beteken dat die moderne siening van kulture as selfstandige entiteite wat stabiel, staties, konsistent is, agterhaal is deur 'n disparate, dog dinamiese en organiese verstaan van kultuur. "Whether or not culture is a common focus of agreement, culture binds people together as a common focus for engagement" (Tanner 1997:57). So word kultuur 'n relasionele nis ('n konteks) binne 'n globale netwerk. Die uniekheid is geleë in die appropriasie, weerstand, kompromie van sake en altyd dinamies. Relatiwiteit vind sy pendule in tyd en plek. Respek vir verskille en partikulariteit bestaan dus en daarom ook eie oortuigings met die korrektief van toereikende kategorië̈. Lindbeck (1989:271) het hierdie gedagte ook elders "reconciliation without capitulation" genoem. PainterMorland (2001:127) stel die waarde van die verskeidenheid so:

\footnotetext{
"Unapologetic" must be understood in two ways: it involves witnessing to one's own religious, cultural, political (etc.) values without excuse, but it is also unapologetic in the sense that it is not an exercise in apologetics. One should not be pitting all one's emotional and rational powers against another set of values or beliefs.
}

Ten slotte volg ook 'n verdere opmerking oor die Postliberale teologie se verstaan van simbole, die "woordeskat" van die taal. Steeds geld die algemene reël: "woorde het nie betekenis nie, maar betekenis het woorde." Dit is dus die disseminasie van die betekenis (semiologie). Alle simbole het hulle oorsprong in interpersoonlike verhoudings en sosiale interaksie (Lindbeck 1984:38). Tekens en simbole interpreteer ook die ervaring en nie andersom nie en daarom is die ervaring altyd waarde-gelade. Die woorde en 


\section{Postliberale teologie as teologiese raamwerk}

simboliek is dus die koppelvlak van kommunikasie (oortuigings) tussen mense. Van Huyssteen (1998:158) stel dit na aanleiding van Rolston raak:

In nature, the coping skills are coded on chromosomes. In culture, the skills are coded in craftsmen's traditions, in technology manuals, or in religious rituals, texts, and traditions.... As human beings we have developed a great diversity of cultures, and each heritage is historically conditioned, perpetuated by language, and conventially established precisely by using symbols with locally effective meanings. Therefore, while animals adapt to their niches, human beings adapt their ecosystems to their needs.

'n Godsdiens kom na ons toe in sy tekens en simbole en daarom is dit soos met die aanleer van 'n nuwe taal, wel so dat dit geïnternaliseer word deur gebruik en inoefening. Dit moet dus 'n modus vivendi word. (Vergelyk hier Kierkegaard se argument teen Hegel dat etiese en godsdienstige waardes subjektief toegeëien moet word.) Daar vind wel ook 'n dialektiese proses tussen simbool en ervaring plaas en ervaring genereer ook simboliek, maar altyd binne die gegewe konteks word dit geïnterpreteer as toereikend of nie (Lindbeck 1984:33). Simbole vind boonop hulle betekenis soos stukke in skaakspel, in terme van die netwerk waarbinne dit vir die oomblik funksioneer. Daarom is die sintaksis en die onderliggende paradigma so belangrik.

\section{KORPORATIEWE KULTUUR}

In die ondernemingsbestuur word ook aandag aan kultuur gegee. Gibson en andere (1991:46) oordeel ook dat kultuur in organisasies of ondernemings nie anders is as in die sosiale gemeenskap nie. In lyn hiermee gee Bateman \& Zeithaml (1993:324) dan ook 'n definisie: "Organization culture is the set of important assumptions about the organization and its goals and practices that members of the company share. It is a system of shared values about what is important and beliefs about how the world works." Hieruit behoort duidelik te wees dat kultuur in 'n organisasie of onderneming nie baie anders is nie as 'n raamwerk wat die betrokkenes se gedrag in die werksplek organiseer en rig. Kultuur is in terme van 'n organisasie of onderneming te verstaan soos persoonlikheid in terme van die individu te verstaan is - grootliks onsigbaar, maar nietemin 'n onderliggende raamwerk 
wat betekenis, koers en aktiwiteit konfigureer. Hierbenewens is die plek van simbole, taal, ideologie, rites en mites van groot belang (Gibson et al 1991:48).

Dit was veral Edgar Schein (1999:15-20) wat hierdie elemente bymekaar gebring het. Hy verstaan dit in drie vlakke: Vlak 1 sluit sake soos artefakte en ander skeppings wat waarneembaar is, maar haas onverstaanbaar. Omsendskrywes, versierings, uit-stallings, kantoorinrigting en andere is sodanige voorbeelde. Vlak 2 is die waardes wat vir die betrokkenes saak maak. Waarom maak hulle juis so? Dit is bewustelike, affektiewe behoeftes of begeertes. Vlak 3 weer weerspieël die basiese aannames wat mense maak wat dan hulle gedrag rig. Hier word ook veronderstel die faktore wat 'n rol speel in mense se persepsies, opinies en houdings. Die volgende figuur verduidelik dit skematies (aangepas):

Edgar Schein (1999:16) se Drie Vlak Organisasie Model

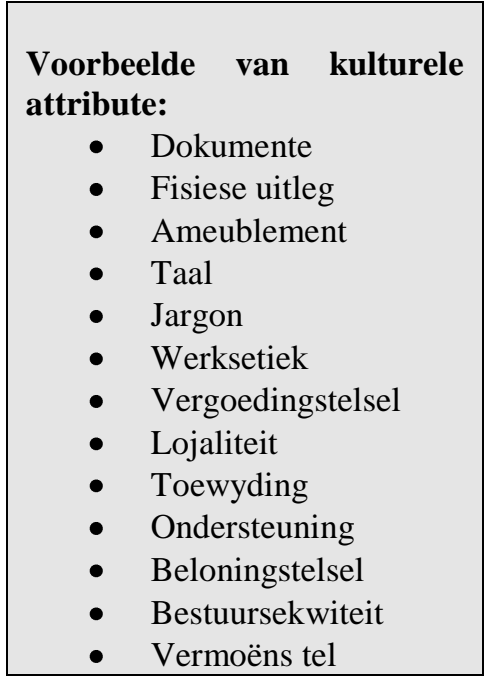

1.

Artefakte en Skeppings:

- Tegnologie

- Kuns

- Waarneembare gedragspatrone

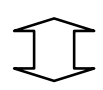

2.

Gekose waardes:

- Toetsbaar in die fisiese omgewing

- Toetsbaar slegs met sosiale konsensus

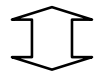

$$
3 .
$$

Onderliggende Aannames:
$\bullet \quad$ Relasie met die omgewing

- Aard van werklikheid, tyd en ruimte

- Aard van mense se natuur

- Aard van mense se aktiwiteit

- Aard van mense se verhoudings
Sigbaar maar dikwels ontsyferbaar

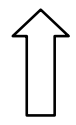

Hoër vlak van waarneming

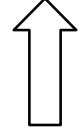

Vanselfsprekende en onsigbare voorbewuste 


\section{Postliberale teologie as teologiese raamwerk}

William Ouchi (1978) het in sy blitsverkoper, Theory $Z$ korporatiewe kultuur van ondernemings beskryf as Tipe A, Tipe J en Tipe $Z$ organisasies. Eersgenoemde is die tipiese Amerikaanse benadering van individualisme, korttermyn, segmentasie terwyl die Japannese tipe weer die klem laat val op permanensie, kollektiwiteit, holisme. Tipe $\mathrm{Z}$ is dan 'n balans hiertussen. Bateman \& Zeithaml (1993:48-50) beskou die volgende sake as die noodsaaklikste kenmerke van korporatiewe kultuur vir die hede: planetêre interafhanklikheid, strewe na uitnemendheid en waarborg van kwaliteit.

Korporatiewe kultuur word gediagnoseer aan werknemers se belewenisse, optrede, simbole, stories, rites en seremonies (Bateman \& Zeithaml 1993:327). Belangrik is die waarneming wat Peters en Waterman gemaak het, naamlik dat uitnemende organisasies, "are unashamedly collectors and tellers of stories, of legends and myths in support of their basic beliefs. Frito-Lay tells service stories. J\&J tells quality stories. 3M tells innovation stories" (Bateman \& Zeithaml 1993:327). Stories kan uiteraard ook wentel om legendariese figure van die organisasie. De Bruyn \& Kruger (1994:183) meen die volgende merkers help om die kultuur te diagnoseer:

- geskiedenis, gebeurtenisse, besluite en persone wat help skep het aan die organisasie se geskiedenis;

- ideale, ambisies en waardes van die sleutelpersone van 'n organisasie en van opinievormers;

- prestasie, motivering en verhoudings van die werknemers;

- organisasieverhale wat belangrike boodskappe dra ten opsigte van prioriteite, waardes, bevoegdhede, toewyding en bekommernisse van werknemers; en

- eienaardighede, insluitende unieke metodes gevolg, benadering tot probleme en reaksie tot sukses of mislukking moet ontleed word.

Korporatiewe kultuur kan ook bestuur, met ander woorde, verander word (Pierce \& Robinson 1991:347-352). Maar onthou, "[C]ulture controls you more than you control culture" (Schein 1999:25). 'n Gevestigde kultuur word natuurlik nie oornag verander nie. Die faktore waaroor bestuur wel beheer het, soos die aanstellings, die bestuursproses (beplanning, organisasie, leiding en beheer), moet voortdurend as instrumente aangewend 
word ten einde 'n kultuur te skep of te versterk (Gibson et al 1991:50). De Bruyn \& Kruger (1994:183) verstaan bestuur van kultuur in terme van toewyding, bevoegdheid en konsekwentheid by die werknemers. 'n Verandering in die korporatiewe kultuur beteken dan 'n graadverskuiwing in een van hierdie faktore. Die uiterlike manifestasie van die onderliggende kultuur is dus nie net indikators nie, maar inderdaad ook instrumente in die bestuursproses. Maar dan moet die fokus van die organisasie duidelik wees.

Omdat sinergie tussen 'n kultuur en strategie in 'n organisasie nagestreef word, sal dit ook die kompeterende voordeel van 'n onderneming medebepaal. Die passing van die kultuur en strategie is nie ' $\mathrm{n}$ eenmalige gebeurtenis nie. Daar moet voortdurend bevestiging wees dat die een die ander ondersteun om die bestaande mededingende voordeel te behou. Daarom is Bateman \& Zeithaml (1993:328) reg om te beweer dat kultuur eintlik begin by die visie van die organisasie wat die werknemers inspireer en meeneem (Schein 1999:14). Die volgende aanhaling van Lindbeck (1984:125-126) strook nogal met hierdie benadering:

In the construction of such scenarios, the crucial difference between liberals and postliberals is in the way they correlate their visions of the future and of the present situations. Liberals start with; experience, with an account of the present, and then adjust their vision of the kingdom of God accordingly, while postliberals are in principle committed to doing the reverse.

Hierdie saak van 'n visie is nie baie anders as wat Abraham gehad toe hy, "uitgesien het na die stad wat vaste fondamente het waarvan God self die ontwerper en bouer is" (Hebr 11:10)! Ek meen dis dieselfde volgorde wat Van Staden (2001:577) handhaaf wanneer hy skryf dat modelle wat in die sosiale wetenskappe ontwikkel is, op Bybelse gegewens toegepas word ten einde te bepaal in welke opsig die Bybel inpas by of afwyk van die algemeen-menslike patroon van optrede.

Die kerk sal nie meer baie lank die eis kan ontkom om 'n tyd-en-plek relevante visie en missie te bepaal wat nie net die gemeenskaplike droom verwoord nie, maar ook 


\section{Postliberale teologie as teologiese raamwerk}

die verlangde koers en die waardes, die styl en die kultuur'. Kan mens praat van 'n "nasionale konvensie" vir die toekoms? Binne so 'n "kultureel-linguistiese raamwerk" sal elkeen 'n bydrae kan maak en word die kloof tussen kateder en kansel kleiner (consensus fidelium). Sodanige matrys (etimologies: mater) sal dan ook die interpretatiewe raamwerk vorm wanneer byvoorbeeld die storie van Gilgal vertel word: As julle nageslag eendag in die toekoms vir julle ouer mense sou vra wat hierdie klipstapel beteken, moet julle vir hulle sê: "Dit is 'n bewys dat Israel op droë grond deur hierdie Jordaan getrek het" (Jos 4:21). Die kerk moet sy storie in die Bybel gaan soek, sy taak hier en nou konsipieer, en dit vertel en verbeeld.

In summary, the alternate model understands religions as idioms for dealing with whatever is most important - with ultimate questions of life and death, right and wrong, chaos and order, meaning and meaninglessness. These are the problems they treat in their stories, myths, and doctrines. They imprint their answers through rites, instruction, and other socializing processes, not only on the conscious mind but in the individual and cultural subconscious.

(Lindbeck 1984:40)

\section{Literatuurverwysings}

Barbour, I 2000. When science meets religion: Enemies, strangers or partners? London: SPCK.

Bateman, T S \& Zeithaml, C P [1990] 1993. Management: Function \& Strategy. Boston: Irwin.

Berkhof, H 1977. The doctrine of the Holy Spirit. Atlanta: John Knox.

Biettie, J [1964] 1993. Other cultures: Aims, methods and achievements in social anthropology. London: Routledge.

Borg, M 1994. Meeting Jesus again for the first time. San Francisco: Harper Collins.

Cobb, J B Jr. 1993. Becoming a thinking Christian. Nashville: Abingdon.

De Bruyn, H E C \& Kruger, S 1994. Strategiese bestuur. Vanderbijlpark: Entrepro.

\footnotetext{
${ }^{7}$ Dieselfde sou gesê kan word van die amalgamasie van die twee teologiese fakulteite aan die Universiteit van Pretoria in 2000. Sien die "Principles and procedures of the Pretoria model" (Wethmar 2000) waarin hierdie leemte ook nie aangespreek word nie.
} 
Dekker, G, De Hart, J \& Peters, J 1997. God in Nederland 1966-1996. Amsterdam: Anthos.

Du Toit, C W 2000. Evolutionary biology as a link between religion and knowledge. HTS 56(2\&3), 506-526).

Frei, H W 1974. The eclipse of Biblical narrative: A study in eighteen and nineteenth century hermeneutics. New Haven: Yale University.

Fretheim, T E \& Froelich, K 1998. The Bible as the Word of God: In a postmodern age. Minneapolis: Fortress.

Geyser, P A 2000. Hermeneutiese uitgangspunte in historiese-Jesus navorsing: Sosiaalwetenskaplike vooronderstellings. HTS 56(2\&3), 527-548.

Gibson, J L, Ivancevich J M \& Donnelly, J H [1973] 1991. Organizations: behaviour, structure, processes. Boston: Irwin.

Hawking, S 1993. Black holes and baby universes and other essays. London: Bantam.

Hawking, S [1988] 1994. A brief history of time: From the big bang to black holes. London: Bantam.

Heyns, J H 1978. Dogmatiek. Pretoria: NG Kerkboekhandel.

Lindbeck, G A 1984. The nature of doctrine: Religion and theology in a postliberal age. Philadelphia: Westminster.

Lindbeck, G A 1989. Ecumenical theology, in Ford, D F (ed), The modern theologians: An introduction to Christian theology in the twentieth century, Vol II, 255-273. Oxford: Blackwell.

Loader, J A 1987. "Tertium datur" - oor die etiese waarheidsbegrip. HTS 43, 47-57.

Macquarrie, J 1997. Jesus Christ in modern thought. 4th Impression. London: SCM.

McFague, S 2000. Life abundant: Rethinking theology and economy for a planet in peril. Minneapolis: Fortress.

McGrath, A E [1990] 1997. The genesis of doctrine: A study in the foundation of doctrinal criticism. Oxford: Blackwell.

McGrath, A E [1997] 2000. Christian theology: An introduction. Oxford: Blackwell.

McGrath, A E 1996. An evangelical evaluation of postliberalism, in Phillips, T R \& Okholm, D L (ed) The nature of confession: Evangelicals \& postliberals in conversation, 23-44. Illinois: Intervarsity Press. 
Mildenberger, F, 1981. Geschichte des deutschen evangelische Theologie im 19. und 20. Jahrhundert. Stuttgart: Kohlhammer. (Theologische Wissenschaft Bd. 10.)

Müller, A M K 1978. Wende der Wahrnehmung: Erwägungen zur Grundlagenkrise in Physik, Medizin, Pädagogik und Theologie. München: Kaiser Verlag.

Müller-Fahrenholz, G 1995. God's Spirit: Transforming a world in crisis. New York: Continuum.

Ott, H [1981] 1999. Die Antwort des Glaubens: Systematische Theologie in 50 Artikeln. Stuttgart: Kohlhammer.

Painter-Morland, M 2001. Dealing with difference and dissensus within the church as organisation. Verbum et Ecclesia 22(1), 115-130.

Phillips, T R \& Okholm, D L (ed) 1996. The nature of confession: Evangelicals \& postliberals in conversation. Illinois: Intervarsity Press.

Pierce, J A \& Robinson, R B 1991. Formulating, implementation and control of competitive strategy. Boston: Irwin.

Placher, W C [1997] 2000. Postliberal theology, in Ford, D F (ed), The modern theologians: An introduction to Christian theology in the twentieth century, 343356. London: Blackwell.

Polkinghorne, J 1998. Science \& theology: An introduction. London: SPCK.

Rasker, A J 1974. De Nederlandse Hervormde Kerk vanaf 1795. Kampen: JH Kok.

Schein, E H 1999. The corporate culture: Survival guide. San Francisco: Jossey-Bass.

Tanner, K 1997. Theories of culture: A new agenda for theology. Minneapolis: Fortress.

Van der Merwe, P J 1996. Kerk en kultuur: 'n Godsdiensteologiese perspektief. HTS 52(3), 671-692.

Van Huyssteen, J W 1998. Duet or dual? Theology and science in a postmodern world. Pennsylvania: Trinity.

Van Huyssteen, J W 1999. The shaping of rationality: Toward interdisciplinarity in theology and science. Grand Rapids: Eerdmans.

Van Ruler, A A 1972. Hoe functioneert de belijdenis?, in Theologisch werk VI, 85-105. Nijkerk: Callenbach.

Van Staden, P 2001. Doop as ritueel van status-transformasie. HTS 57(1\&2), 576-592. 
Ward, G (ed) 2000. The postmodern God: A theological reader. London: Blackwell.

Wethmar, C J 2000. Theological education in an ecumenical context: Principles and procedures of the Pretoria model. Skrif en Kerk 21(2), 1-12

http://www.up.ac.za/academic/theology/news/skrweth.htm). 